\title{
Predicting Impending Bankruptcy From Auditor Qualified Opinions And Audit Firm Changes
}

David L. Senteney, (Email: senteney@ohio.edu), Ohio University Yinning Chen, Ohio University Ashok Gupta, Ohio University

\begin{abstract}
Unlike prior research, we investigate the incremental explanatory power of both auditor qualified opinions and auditor changes beyond the information conveyed by traditional financial statement ratios in predicting bankruptcy. We find that qualified auditor opinion and auditor changes are both important in predicting impending bankruptcy and that auditor changes convey important information not reflected in auditor qualified opinions alone. In fact, we find compelling evidence that auditor changes provide incremental explanatory power in predicting impending firm failure beyond what is conveyed by auditor qualified opinions and traditional financial statement ratios considered jointly. Although the existing relevant literature provides no empirical evidence in this regard to our knowledge, this result is intuitive as one motivation for clients to change audit firms is to seek less conservative professional auditors as a strategic response to manifestation of the financial statement effects of bankruptcy.
\end{abstract}

\section{INTRODUCTION}

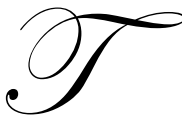

he probability of firm financial failure is crucially important information to shareholders, creditors, management, and the various company stakeholders and the assumption of firm status as one of being a "going concern" is important to the internal and external constituencies as well. In practice, professional groups of both auditors and security analysts serve as an effective market mechanism for monitoring firm financial health and communicating to the various external constituencies the likelihood of firm failure.

Generally, three approaches are used to predict impending firm bankruptcy.

\section{Financial Statement Ratio-Based Prediction}

Beaver [1966] and Altman [1968] in addition to many others (c.f., Altman, Haldeman, and Narayanan [1977], Collins [1980], Ohlson [1987], and Platt and Platt [1991]) have provided ample compelling empirical evidence establishing the financial statement ratio-based prediction model specification as the premier specification in forecasting impending firm failure. Because the explanatory variables used in firm failure prediction models should vary systematically between bankrupt and non-bankrupt firms, financial statement-based ratios are intuitively appealing as reflecting underlying economic differences between financially healthy and financially distressed sets of firms. However, there is disagreement regarding which of the various financial statement ratios perform best. This result is somewhat intuitive as the same set of financial statement-based ratios is unlikely to perform equally well for all firms across their varying economic circumstances in predicting impending bankruptcy.

\section{Qualified Auditor Opinions Based Prediction}

A substantial body of literature supports the contention that the general as well as the professional public expect that qualified auditor opinions serve as early warnings signals of impending firm bankruptcy (Journal of 
Accountancy [1982, 1983], and Mednick [1986], and Connor [1986]). Of course, no one expects that qualified auditor opinions serve as perfect signals of firm failure but rather that they serve as good warning signs commensurate with a significant association with actual bankruptcies. Evidence presented in Hopwood, McKeown, and Mutchler [1989, 1994] solidly supports assertions that auditor opinions qualified for going concern, consistency, and subject-to issues significantly improve the ability of traditional financial ratio-based models to predict impending bankruptcy. However, neither financial statement ratio-based prediction models nor auditor opinion modifications are very good predictors of bankruptcy when population proportions, differences in misclassification costs, and financial stress levels are considered (Hopwood, McKeown, and Mutchler [1994, p.425]).

\section{Auditor Changes Based Prediction}

Another aspect of the auditor-client relationship which bears directly on both auditor qualified opinions and firm failure is auditor changes. Chow and Rice [1982] provide somewhat marginal evidence that auditor changes are associated with qualified auditor opinions in their examination of a phenomenon commonly referred to as "opinion shopping". In addition, Schwartz and Menon [1985] provide contingency analysis results suggesting that auditor qualified opinions as well as auditor changes are associated with subsequent firm bankruptcy. While possible motivations for audit clients seeking auditor firm changes may include disputes over accounting methods, displeasure over the type of audit opinion, dissatisfaction with an auditor's failure to detect internal control weaknesses or inaccuracies in accounting records, changes in corporate management, need for additional audit services, and conflict over audit fees, failing firms intuitively have incentives to seek less conservative auditors (i.e., auditors preferring income decreasing applications of generally accepted accounting principles) as financial statement indicators of firm failure begin to appear. Although the existing empirical evidence indicates that the association between auditor changes and subsequent firm failure is not as strong as the association between auditor qualified opinion and subsequent firm bankruptcy it is none the less significant and may provide additional important source of information about clients more aggressive preference for application of accounting principles beyond that conveyed by the qualified auditor opinion which is useful in explaining and anticipating firm bankruptcy. The usefulness of auditor changes in predicting firm failure and its incremental explanatory ability beyond the information conveyed by auditor qualified opinions alone remains to an open empirical question in the existing relevant research literature.

\section{FOCUS OF CURRENT RESEARCH}

The purpose of current research is to integrate auditor changes (AC), auditor qualified opinions (AQO), and traditional financial statement ratios (FSR) in explaining impending firm bankruptcy. We approach the task of assessing the incremental explanatory power of $\mathrm{AQO}$ and $\mathrm{AC}$ (i.e., both individually and jointly) using log-linear odds ratio logistic regression models using traditional financial statement ratios as the baseline. Specifically, we test null hypotheses formulated to yield inferences regarding:

(1) the explanatory power of $\mathrm{AQO}$ together with $\mathrm{AC}$ in predicting bankruptcy;

(2) the incremental explanatory power of client AC beyond AQO in predicting bankruptcy;

(3) the incremental explanatory power of AQO beyond FSR in predicting bankruptcy;

(4) the incremental explanatory power of AC beyond FSR in explaining firm bankruptcy; and

(5) the incremental explanatory power of client AC beyond the information conveyed by AQO and FSR in predicting firm failure.

Our most noteworthy result indicates that qualitative information regarding auditor changes prior to firm financial failure provides significant explanatory and incremental explanatory power in log-linear logistic regression prediction models of impending firm bankruptcy. Specifically, we find that (1) both AQO and AC are significantly associated with increased probability of bankruptcy; (2) AC have significant incremental explanatory power beyond that conveyed by AQO in predicting impending firm failure; (3) both $\mathrm{AQO}$ and $\mathrm{AC}$ have incremental explanatory power above the information provided by traditional FSR in predicting bankruptcy; and (4) AC have incremental explanatory power beyond the information convey 
The remainder of this paper is organized in the following manner. The review of previous relevant research and discussion of underlying motivation and intuition for this study are discussed in the first section. The second section of the paper discusses the sample firms selection and characteristics and the empirical statistical methods and the specification of the log-linear odds ratio logistic regression model employed. The third section describes the empirical results of the logistic regression model estimation and the results of our specific hypotheses tests as well as the interpretation of the results in light of the existing research literature and the initial purpose of the paper. The final section of the paper discusses the conclusions of this paper in the context of the relevant research literature and provides some suggestions for future research.

\section{LITERATURE REVIEW}

\section{Financial Statement Ratios (FSR) and Bankruptcy Prediction}

Beaver [1966] and Altman [1968] in addition to many others (c.f., Altman, Haldeman, and Narayanan [1977], Collins [1980], Ohlson [1987], and Platt and Platt [1991]) have provided ample compelling empirical evidence establishing the financial statement ratio-based prediction model specification as the premier specification in forecasting impending firm failure. Other bankruptcy prediction models in the related research literature have employed approaches utilizing firm cash flows, equity security returns, and equity security return variation as explanatory independent variables to predict impending company failure. The existing research literature indicates that all of the groups of explanatory variables are statistically important in the year preceding firm failure. However, a preponderance of the empirical evidence indicates that the financial statement ratio-based approach established by Beaver [1966] and Altman [1968] is the most effective in explaining the likelihood of firm default. Three years prior to firm failure the cash flow-based bankruptcy prediction models perform with markedly increased ability relative to its performance in the year prior to bankruptcy, however, the financial statement ratio-based specifications of the firm failure prediction models nonetheless appear superior.

Auditors frequently employ the financial statement ratio-based prediction models as an integral part of their requisite analytical review procedures in assessing the appropriateness of the "going concern" assumption underlying historical cost-based accounting financial statements and the auditors opinion regarding the particular application of the generally accepted accounting principles (GAAP) used to prepare the financial statements. Equity security analysts frequently employ financial statement ratio-based bankruptcy prediction models in evaluating the financial status of the firms which they follow for valuation purposes along with the accompanying dissemination of the results of their analyses through the various public channels. Because the explanatory variables used in firm failure prediction models should vary systematically between bankrupt and non-bankrupt firms, financial statement-based ratios are intuitively appealing as reflecting underlying economic differences between financially healthy and financially distressed sets of firms.

Discussion regarding the best performing bankruptcy prediction model generally acknowledges the superiority of the financial statement ratio-based specifications, however, there is disagreement regarding which of the various financial statement ratios perform best. This result is somewhat intuitive as the same set of financial statement-based ratios is unlikely to perform equally well for all firms across their varying economic circumstances in predicting impending bankruptcy. Boritz [1991] identifies more than sixty-five financial statement-based ratios used with varying but substantial degrees of success in the existing bankruptcy prediction literature. Hamer [1983] asserts that the incremental or differential ability of the different financial statement ratios to predict impending firm failure is negligible. Karels and Prakash [1987] admonish empirical researchers to carefully choose the financial statement ratios specifying bankruptcy prediction models as no specification appears to dominate, although there is some empirical evidence that specifications in Altman [1968] and Altman, Haldeman, and Narayanan [1977] appear to outperform other specifications. Similar bankruptcy prediction model specification has been employed in the accounting literature following upon Beaver [1966], Deakin [1972], and Libby [1975] which reported substantial explanatory success using the financial statement ratios presented in Table as independent variables. 
Table 1: Financial Ratios Used To Predict Firm Bankruptcy

\begin{tabular}{|l|l|l|}
\hline LIQUIDITY RATIOS & X1 & Cash / Total Assets \\
\hline Cash to Total Assets Ratio & X2 & Current Assets / Current Liabilities \\
\hline Current Assets to Current Liabilities Ratio & X3 & Current Assets / Sales \\
\hline Current Assets to Sales Revenue Ratio & X4 & Current Assets / Total Assets \\
\hline Current Assets to Total Assets Ratio & X5 & Long Term Debt / Total Assets \\
\hline FINANCIAL LEVERAGE RATIO & X6 & Net Income / Total Assets \\
\hline Debt to Total Assets Ratio &
\end{tabular}

These variables may be thought of as an intersection of the variables identified as successful in predicting bankruptcy in the Beaver [1966] and Deakin [1972] studies or as the variables identified as significant predictors of firm failure in Libby [1975] plus long-term debt to total assets identified in Beaver [1966] and Deakin [1972]. The explanatory variables which have been selected in the current study cover the three dimensions (i.e., return-on-assets, leverage, and liquidity) identified in Zmijewski [1984] as the most successful predictors of firm failure in prior research studies.

\section{QUALIFIED AUDITOR OPINIONS AND BANKRUPTCY PREDICTION}

Research regarding the incremental explanatory power of qualified auditor opinions in prediction of firm financial failure seems to have begun with Altman and McGough [1974] who initially identified the link between bankruptcy and auditor opinion decisions in the accounting research literature. Pioneering work in this area reflects the interaction of the various dimensions of the firm bankruptcy and auditor opinion studies such as predicting auditor opinion on bankrupt companies and comparing the accuracy of auditor and model predictions of bankruptcy.

Levitan and Knoblett [1985], Mutchler [1985], Schwartz and Menon [1985], Mutchler, Hopwood, and McKeown [1997], and McKeown, Mutchler, and Hopwood [1991] model the auditors opinion qualification decision and predict the opinion modification event for samples of bankrupt and non-bankrupt companies. These research studies focus on the importance of financial statement ratios and other financial variables in predicting auditor opinion qualification. Chen and Church [1992] investigate going-concern auditor opinion modifications for a sample of 127 first time going-concern qualifications from 1983 to 1986. They found that including auditor opinion qualifications in the prediction model using only financial statement ratios increased the explanatory power of the prediction model from $38 \%$ to $93 \%$ ( a $144 \%$ increase); providing compelling evidence as to the importance of the additional information provided by auditor opinions.

Schwartz and Menon [1985] investigate the auditor-distressed client issue using a revenue-matched (i.e., revenue as a proxy for sample firm size) sample of 132 bankrupt and non-bankrupt firms in the time period from 1974 to 1982. Using various contingency analyses they investigate the relation between auditor qualified opinions and auditor changes and impending firm failure. While Chow and Rice [1982] find that incidences of auditor changes are more prevalent following upon qualified auditor opinions, Schwartz and Menon [1985] suggest that auditor changes may also be the result of an "yet-to-be-specified" outcome which they hypothesize is client financial distress. The Schwartz and Menon's [1985] rationale for the observance of auditor changes is that if the client wants to use more aggressive accounting principles (i.e., revenue and asset recognition as a strategic response to deteriorating financial position and impending bankruptcy) than the auditor will permit and the client does not want to receive a qualified auditor opinion at that time then the auditor change is the natural outcome in order to defer the event of an auditor opinion qualification. The important research result observed from the Schwartz and Menon [1985] study with implications for this research is the observed higher occurrence of auditor changes among bankrupt firms than nonbankrupt firms. For their sample, $27 \%$ of bankrupt firms had changed auditors during the study period and $73 \%$ of the firms changing audit firms were bankrupt firms. However, contrary to some prior research findings, these authors conclude that qualified auditor opinions appear not to be a primary factor in driving auditor changes for the sample and time periods examined. For failing firms the tendency appears to be to change to a smaller auditor firm, Schwartz and Menon [1985, p.258]. These results suggest that auditor changes may provide important information beyond that 
conveyed by qualified auditor opinions alone in identifying financially distressed firms.

Hopwood, McKeown, and Mutchler [1989] investigate the incremental explanatory power of auditors qualified opinions in predicting firm failure. Using a sample of 60 bankrupt and 55 non-bankrupt firms from 1974 to 1981 in the log-linear odds ratio logistic regression model, they conclude that when tested jointly with financial statement ratio independent variables the consistency exception and going concern auditor opinion modifications were significantly associated with bankruptcy at the $\square=0.05$ confidence level. The subject-to audit opinion qualification appeared to perform somewhat more modestly in predicting bankruptcy.

In a study of time periods 1974 to 1985, Hopwood, McKeown, and Mutchler [1994] compare the accuracy of auditor and model predictions of firm failure for a sample of 134 bankrupt firms and 160 non-bankrupt firms. The particularly innovative aspect of this research is that the authors partition the sample firms into stressed and nonstressed subsets. Contrary to prior research, they found that financial statement ratio-based bankruptcy prediction models do not outperform auditor opinion qualifications for going concern issues in predicting firm failure. However, noteworthy is the observation that neither financial statement ratio-based firm financial failure prediction models or auditor opinion modifications are very good predictors of bankruptcy when population proportions, differences in misclassification costs, and financial stress levels are considered (Hopwood, McKeown, and Mutchler [1994, p.425]).

\section{Auditor Changes And Bankruptcy Prediction}

Differences in professional training may give rise to differences in management and auditor opinions as to the appropriate application of generally accepted accounting principles (GAAP). Consequently, published financial statements are the product of compromise between management and auditor opinions as to the appropriate application of GAAP. Dye [1991] observes that compromise may not be reached in some instances and that auditor changes are a natural result of negotiation failure. Antle and Nalebuff [1991] suggest that auditor changes are more likely to occur when the auditor believes that the proper application of GAAP produces a lower earnings measurement. DeFond and Jiambalvo [1993] indicate that nearly all of the Securities and Exchange Commission 8-K filing cases which they examined the disagreement between the auditor and the client originated in GAAP differences which produced a lower audited earnings figure.

One compelling factor that influences auditors' choice of qualified opinion is litigation risk following upon client bankruptcy. A reasonable proposition is that auditors ask that clients use more conservative accounting principles as a mechanism to reduce the litigation risk following possible client bankruptcy (Pratt and Stice [1994], Simunic and Stein [1996], Krishnan and Krishnan [1996]). Substantial prior research (e.g., Lys and Watts [1994] and St. Pierre and Anderson [1984]) indicates that instances of litigation are more likely to occur following upon income overstatements and that virtually no instances of litigation follow upon income understatements. Consequently, under certain circumstances auditors are likely to be more conservative in their preferences for accounting principles choices than management and auditor changes are likely to occur when management believes that they can change to a audit firm permitting more aggressive applications of accounting principles. The new auditor may be willing to accept the client's relatively more aggressive accounting principles choices if they have difference risk assessments, risk preferences, or risk of clientele portfolio (Magee and Tseng [1990], Balachandran and Ramakrishnan [1987], and Simunic and Stein [1990]).

Chow and Rice [1982] provide a uniquely thorough analysis of auditor changes for a sample of 9,460 firms for the years 1973 and 1974. Their logistic regression model employs auditor opinions, management changes, merger activity, new financing, and other reason given as explanatory variables in predicting auditor changes. Their results (Table 2, p.330) indicate that the qualified auditor opinion is important in determining instances of auditor changes, and is the only variable which they include in the specification of the logistic regression model which is significant at the $\square=0.05$ confidence level. These researchers conclude that "firms tend to switch auditors after receiving qualified opinions" (Chow and Rice [1982 p.334]). They posit one possible explanation for this finding being that firms tend to change to audit firms giving relatively fewer qualified opinions after receiving a qualified opinion. However, their evidence is not consistent with the contention that firms change to an audit firm giving relatively fewer qualified opinions after receiving a qualified opinion. In contrast to Chow and Rice [1982], however, Schwartz and Menon 
[1985] find that auditor opinion modifications appear not to be the underlying force motivating auditor changes for the sample firms and time periods which they examined, but that for failing firms the tendency seems to be switching to a smaller (and presumably less conservative) auditor firm.

\section{RESEARCH DESIGN}

\section{Sample Selection and Variable Definitions}

We use the Standard and Poor's Compustat data files to identify firms indicating that they are involved in bankruptcy proceedings in the footnotes accompanying their audited financial statements for any of the years 1990 through 1998. We use a matching procedure to identify non-bankrupt firms which are in the same industry as each of the bankrupt firms and closest to the size where size is measured in terms of sales and assets in the year preceding bankruptcy. A total of 896 firms are included in the study. Distribution of firms in our sample is as presented in Table 2.

Table 2: Firms In The Sample

\begin{tabular}{|l|c|c|}
\hline Total Number of Firms in Sample & 896 & $100 \%$ \\
\hline Number of non-bankrupt firms & 424 & $47 \%$ \\
\hline Number of Bankrupt Firms & 472 & $53 \%$ \\
\hline Number of Firms with Auditor Change & 438 & $49 \%$ \\
\hline Number of Firms with NO Auditor Change & 458 & $51 \%$ \\
\hline Number of Firms with Qualified Auditor Opinion & 768 & $86 \%$ \\
\hline Number of Firms with NO Qualified Auditor Opinion & 128 & $14 \%$ \\
\hline
\end{tabular}

In our analyses, the variable Bankrupt $\mathbf{t}_{\mathbf{i}}$ for the $\mathrm{i}^{\text {th }}$ firm is assigned a value of zero if the firm is not bankrupt and is assigned a value of one if the firm is a bankrupt firm. We obtain auditor opinion and audit firm identification data from the Standard and Poor's Compustat data files for the years examined in this study. The variable Qualified for the $\mathrm{i}^{\text {th }}$ firm takes a value zero if the firm (either bankrupt or non-bankrupt) did not receive a qualified auditor opinion during the period under examination and is assigned a value of one if it does receive a qualified auditor opinion during the time period studied. A firm (bankrupt or non-bankrupt) is considered to have received a qualified auditor opinion if they receive an auditor opinion other than an unqualified opinion in any of the ten years employed in this study. The variable Change $\mathbf{~}_{\mathbf{i}}$ for the $\mathrm{i}^{\mathrm{t}}$ firm is assigned a value of zero if the sample firm (either non-bankrupt or bankrupt) did not have an auditor change occur and takes a value of one if the firm did have an auditor change. An auditor change has occurred if the current year auditor is not the same as the previous year's auditor. Financial statement ratio variables (see Table 1) used as benchmarks for evaluating the incremental explanatory power of auditor qualified opinions and auditor changes are also obtained from the Standard and Poor's Compustat data files and are calculated.

\section{RESULTS}

\section{Association Between Bankruptcy Status, Audit Opinions, And Auditor Changes}

Table 3 shows cross-tabs of the sample firms over the various partitions of the data used in the log-linear analyses used in this study. First panel of Table 3 shows the distribution of the bankrupt firms over qualified and unqualified auditor opinion partitions. As indicated, our sample of firms is divided approximately evenly between bankrupt and non-bankrupt firms. ${ }^{1}$ About $85 \%$ of the sample firms received some type of auditor qualification over

1

1. The data availability constraint makes the number of firms vary slightly over the ten year study period as the data availability varies from year to year and consequently the number of bankrupt and nonbankrupt firms comprising the sample is not equal. We do not use a matched pair design and seek only balance from the matching procedure and because the statistical techniques employed are not dependent on a matched-pair design we do not expect the few firms with missing data items to impact the results. 
the ten year time period examined while only about $50 \%$ were eventually bankrupt. As shown by the Chi-Squared test statistic in Table 3 the null hypothesis that the qualified auditor opinions are distributed evenly over the bankrupt and non-bankrupt partitions of the sample firms is rejected at the $\square=0.05$ confidence level using two-tailed hypothesis tests. Our definition of qualified auditor opinion includes anything other than an unqualified opinion and is very general and is one reason why auditor changes may provide important incremental information in identifying firm failure. $^{2}$

Table 3: Association Between Bankruptcy Status, Audit Opinions, And Auditor Changes

\begin{tabular}{|c|c|c|c|}
\hline \multicolumn{4}{|c|}{ Hypothesis 1: There is NO association between firm's bankruptcy status and audit opinions } \\
\hline & $\begin{array}{l}\text { Number of Firms Receiving } \\
\text { Un-Qualified Audit Opinions }\end{array}$ & $\begin{array}{c}\text { Numbers of Firms Receiving } \\
\text { Qualified Audit Opinions }\end{array}$ & Total \\
\hline $\begin{array}{l}\text { Number of Non-Bankrupt } \\
\text { Firms }\end{array}$ & $\begin{array}{c}119 \\
(13 \%)\end{array}$ & $\begin{array}{c}305 \\
(34 \%)\end{array}$ & $\begin{array}{c}424 \\
(47 \%)\end{array}$ \\
\hline Number of Bankrupt Firms & $\begin{array}{c}9 \\
(1 \%)\end{array}$ & $\begin{array}{c}463 \\
(52 \%)\end{array}$ & $\begin{array}{c}472 \\
(53 \%)\end{array}$ \\
\hline Total & $\begin{array}{c}128 \\
(14 \%)\end{array}$ & $\begin{array}{c}768 \\
(86 \%)\end{array}$ & $\begin{array}{c}896 \\
(100 \%)\end{array}$ \\
\hline \multicolumn{4}{|c|}{$\begin{array}{l}\chi^{2} \text { Value }=124.82, \mathrm{p}-\mathrm{value}<0.0001 \\
\text { Conclusion: Hypothesis is rejected at } 95 \% \text { confidence level. There is an association between receiving qualified audit opinion } \\
\text { and bankruptcy of the firm. }\end{array}$} \\
\hline
\end{tabular}

\begin{tabular}{|c|c|c|c|}
\hline & $\begin{array}{l}\text { Number of Firms that Did } \\
\text { NOT Change Auditors }\end{array}$ & $\begin{array}{l}\text { Numbers of Firms that } \\
\text { Changed Auditors }\end{array}$ & Total \\
\hline $\begin{array}{l}\text { Number of Non-Bankrupt } \\
\text { Firms }\end{array}$ & $\begin{array}{c}249 \\
(28 \%)\end{array}$ & $\begin{array}{c}175 \\
(19 \%)\end{array}$ & $\begin{array}{c}424 \\
(47 \%)\end{array}$ \\
\hline Number of Bankrupt Firms & $\begin{array}{c}189 \\
(21 \%)\end{array}$ & $\begin{array}{c}283 \\
(31 \%) \\
\end{array}$ & $\begin{array}{c}472 \\
(53 \%) \\
\end{array}$ \\
\hline Total & $\begin{array}{c}438 \\
(49 \%)\end{array}$ & $\begin{array}{c}458 \\
(51 \%)\end{array}$ & $\begin{array}{c}896 \\
(100 \%)\end{array}$ \\
\hline \multicolumn{4}{|c|}{$\begin{array}{l}\chi^{2} \text { Value }=31.20, \mathrm{p} \text {-value }<0.0001 \\
\text { Conclusion: Hypothesis is rejected at } 95 \% \text { confidence level. There is an association between Auditor Change and bankruptcy } \\
\text { of the firm. }\end{array}$} \\
\hline
\end{tabular}

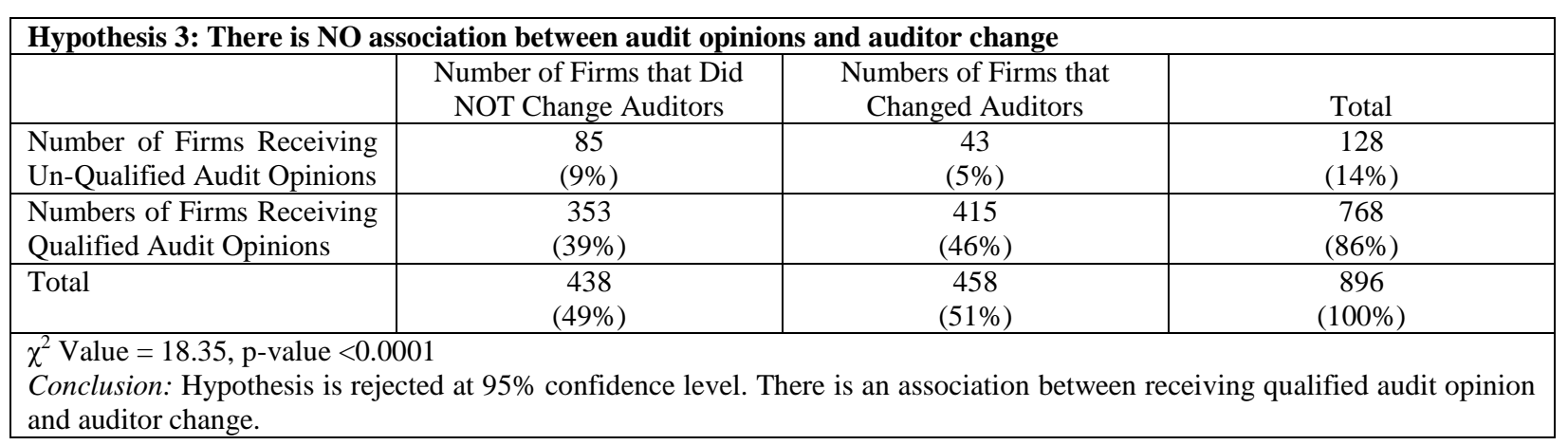

2. Prior research such as Hopwood, McKeown, and Mutchler [1991] has treated any opinion modification option other than the going concern option as being an unqualified auditor opinion. Over the time-period examined in this research the auditor opinion modification options (i.e., other that unqualified and unaudited) available are qualified, qualified with additional language, and adverse. Our research does not differentiate between these audit opinion types as we know of no a priori reason indicating that any one of the current auditor opinion modification options is more associated with impending firm bankruptcy than any of the others. As a preponderance of the empirical research examining the association of auditor opinions with impending firm failure employ the going-concern, subject to, and consistency audit opinion modification options, the issue of the association of qualified, qualified with additional language, and adverse opinions types (arguably a more coarse information set) remains an open empirical question. 
Second panel of Table 3 shows the distribution of sample firms over the bankrupt and non-bankrupt and the auditor change and no auditor change partitions. The sample is divided about evenly among firms that did not change auditors $(49 \%)$ and those that did change auditors (51\%) sometime during the ten-year study period. Of the firms that did change auditors during the ten-year study period, fewer than one-half (38\%) did not fail and more than one-half (62\%) subsequently went bankrupt sometime during the ten-year study period providing an initial indication that auditor changes may provide important information about impending firm failure. The null hypothesis that the auditor changes are distributed evenly over the bankrupt and non-bankrupt partitions of the sample firms is rejected at the

$\square=0.05$ confidence level as indicated by the result of the two-tailed Chi-Squared test.

Third panel of Table 3 shows the distribution of the sample firms over the auditor opinion and auditor change partitions. Particularly noteworthy is the observation that the correspondence between auditor qualified opinions and auditor changes is high although far from perfect. More than half (415/768 or 54\%) of the firms receiving qualified auditor opinions also had changed auditors sometime during the ten-year study period. Strikingly, nearly all (415/458 $=91 \%$ ) of the firms changing auditors also received some type of auditor opinion modification during the ten-year study period. The null hypothesis that the auditor changes are distributed evenly over the unqualified and qualified auditor opinion partitions of the sample firms is rejected at the $\square=0.05$ confidence level as shown by the magnitude of the two-tailed Chi-Squared test.

\section{DIFFERENCES IN FINANCIAL RATIOS BETWEEN BANKRUPT AND NON-BANKRUPT FIRMS}

Table 4 shows descriptive statistics for the financial statement ratios used in the log-linear logistic regression analysis as a baseline to gauge the incremental explanatory power of auditor qualified opinions and auditor changes. A priori one would intuitively expect bankrupt and non-bankrupt firms to exhibit differences in return on assets, leverage, and liquidity measures derived from accounting financial statements. Statistical t-tests of the null hypotheses of no difference in each of the financial statement ratios means is shown in the last column. The results indicate that there are significant differences in the means between the bankrupt and non-bankrupt firms at the 95\% ( $\square=0.05$ ) confidence level for the cash to total assets (x1) ratio and the current assets to current liabilities (x2) ratio. For the other four financial statement ratios there is no significant difference between the means of the variables for the bankrupt and non-bankrupt firms at 95\% confidence level. For the cash to total assets ratio (X1) and current assets to current liabilities ratio (X2) the values for these liquidity measures are significantly larger at the $\square=0.05$ confidence level for the non-bankrupt firms than for the bankrupt firms reflecting the intuitive observation that non-bankrupt firms are significantly more liquid than bankrupt firms. For the current assets to sales ratio (X3) and the current assets to total assets ratio (X4) the differences in mean values for the bankrupt and non-bankrupt firms are not significant at the $\square=0.05$ confidence level. The mean value of the long-term debt to total assets ratio (X5) is larger for nonbankrupt firms than for bankrupt firms indicating the ability of non-bankrupt firms to successfully carry more debt but is not significantly different between the two groups of sample firms at the $\square=0.05$ confidence level. The mean value of the net income to total assets ratio (X6) is less than zero for both non-bankrupt and bankrupt sets of sample firms and is smaller in absolute value for non-bankrupt firms than for bankrupt firms as one would expect and the difference among the two sets of sample firms is not significant at the $\square=0.05$ confidence level.

\section{LOG-LINEAR LOGISTIC REGRESSION MODELS TO PREDICT BANKRUPTCY}

Log-linear analysis is a generic manner of referring to a class of techniques for estimating statistical model parameters and testing related statistical hypotheses employing data which are qualitative in nature such as in the current research. In addition, the logistic regression equation predicts the natural logarithm of the odds of the observation having one qualitative property or another (i.e., in this research the ratio of the probability of bankruptcy to the probability of non-bankruptcy). Consequently, the coefficients can be used to estimate the odds ratios for each of the independent variables used in estimating the logistic regression model.

In the first stage of the analyses presented in this study we introduce auditor qualified opinion and auditor change variables as independent variables in logistic regression equations individually and then jointly. We introduce the auditor qualified opinion and auditor change variables to first establish the sign and the magnitude of the 
coefficients individually in predicting bankruptcy for our sample and to facilitate comparison with prior research studies. We subsequently examine the variables jointly in logistic regression in order to conduct tests of the incremental explanatory power of auditor changes relative to qualified auditor opinions and to compare the signs and magnitudes of the qualified auditor opinion and auditor opinion coefficients to facilitate inferences regarding their relative importance in predicting sample firm financial.

Table 4: Differences in Financial Ratios between Bankrupt and Non-Bankrupt Firms

\begin{tabular}{|c|c|c|c|c|c|c|c|}
\hline & Financial Ratio & Type of Firm & Mean & Std. Dev & Maximum & Minimum & $\begin{array}{l}\text { T-Stat } \\
\text { (p-value) }\end{array}$ \\
\hline \multirow{2}{*}{ X1 } & \multirow{2}{*}{ Cash to Total Assets } & Non-Bankrupt & 0.1476 & 0.2288 & 1.0000 & 0.0000 & \multirow{2}{*}{$\begin{array}{l}3.78 \\
(0.0002)\end{array}$} \\
\hline & & Bankrupt & 0.0957 & 0.1579 & 0.9610 & 0.0000 & \\
\hline \multirow{3}{*}{$\mathrm{X} 2$} & \multirow{3}{*}{$\begin{array}{l}\text { Current Assets to Current } \\
\text { Liabilities }\end{array}$} & & & & & & \multirow{3}{*}{$\begin{array}{l}4.16 \\
(0.0001)\end{array}$} \\
\hline & & Non-Bankrupt & 2.4186 & 4.0918 & 51.1690 & 0.0000 & \\
\hline & & Bankrupt & 1.3842 & 2.0972 & 17.8310 & 0.0000 & \\
\hline & & & & & & & \\
\hline \multirow{2}{*}{$\mathrm{X} 3$} & \multirow{2}{*}{ Current Assets to Sales } & Non-Bankrupt & 2.6893 & 29.9018 & 539.2500 & 0.0100 & \multirow{2}{*}{$\begin{array}{l}1.18 \\
(0.2402)\end{array}$} \\
\hline & & Bankrupt & 0.7373 & 3.2649 & 56.5660 & 0.0300 & \\
\hline & & & & & & & \\
\hline \multirow{2}{*}{ X4 } & \multirow{2}{*}{ Current Assets to Total Assets } & Non-Bankrupt & 0.4669 & 0.2762 & 1.0000 & 0.0000 & \multirow{2}{*}{$\begin{array}{l}-1.30 \\
(0.1954)\end{array}$} \\
\hline & & Bankrupt & 0.4941 & 0.2661 & 1.0000 & 0.0080 & \\
\hline \multirow{3}{*}{ X5 } & \multirow{3}{*}{$\begin{array}{l}\text { Long Term Debt to Total } \\
\text { Assets }\end{array}$} & & & & & & \multirow{3}{*}{$\begin{array}{l}1.18 \\
(0.2386)\end{array}$} \\
\hline & & Non-Bankrupt & 0.8070 & 8.1291 & 118.5600 & 0.0000 & \\
\hline & & Bankrupt & 0.3396 & 0.6658 & 8.0580 & 0.0000 & \\
\hline \multirow{2}{*}{ X6 } & \multirow{2}{*}{ Net Income to Total Assets } & Non-Bankrupt & -0.6354 & 3.8848 & 0.3200 & -30.0000 & \multirow{2}{*}{$\begin{array}{l}0.50 \\
(0.6152)\end{array}$} \\
\hline & & Bankrupt & -0.7822 & 4.3642 & 0.2450 & -47.3900 & \\
\hline
\end{tabular}

\section{Model 1: Auditor Qualified Opinion Alone Predicting Firm Bankruptcy}

Equation (1) shows the logistic regression for qualified auditor opinion alone predicting firm failure. Prior research indicates that auditor going concern qualified opinions, which specifically address firm failure, are strongly associated with increasing probability of firm failure and that other forms of auditor opinion modifications are considerably less associated with probability of bankruptcy. Consequently, we expect that the association between our definition of auditor qualified opinions and probability of firm failure may be considerably weaker than the coefficient for the going-concern opinion modification considered individually because of the degree of aggregation using our definition of the qualified auditor opinion (i.e., as the going concern opinion is no longer available as an explicit modification option) but nonetheless positively associated with the probability of firm bankruptcy. ${ }^{3}$ Consequently, we expect that $\mathrm{a}_{1}$ will be significantly greater than zero at the $\square=0.05$ confidence level and we test the one-tailed null hypothesis $\mathrm{H}_{01}: \mathrm{a}_{1} \square 0$ employing Equation (1) below.

Probability of Firm Bankruptcy $=a_{0}+a_{1}$. Qualified ${ }_{i}+e_{1 i}$

\footnotetext{
3. The definition of the qualified auditor opinions employed in this research includes (1) unqualified with an additional language with includes and additional explanatory paragraph to the standard report (circa 1988) and is one format in which going concern exceptions may be communicated under the present guidelines, (2) qualified auditor opinions based upon scope limitations and unsatisfactory accounting principle presentation, (3) disclaimer of an opinion which is another manner in which going concern issues may be communicated under current guidelines, and (4) adverse auditor opinions. We do not consider unaudited firms in any manner. Consequently, following current guidelines, the only auditor opinion considered to be unqualified in this research is the strictly unqualified auditor opinion.
} 


\section{Model 2: Auditor Change Alone Predicting Firm Bankruptcy}

Equation (2) illustrates the logistic regression model for auditor changes individually in predicting pending bankruptcy. The existing research regarding auditor changes by bankrupt companies suggests that auditor changes should be positively associated with firm failure although perhaps more modestly so than auditor qualified opinion. Consequently, we a priori believe that $b_{1}$ will be significantly greater than zero at the $\square=0.05$ confidence level and we test the one-tailed null hypothesis $\mathrm{H}_{02}: \mathrm{b}_{1} \square 0$ employing Equation (2) below.

Probability of Firm Bankruptcy $=b_{0}+b_{1}$. Change $e_{i}+e_{2 i}$

Model 3: Auditor Qualified Opinion \& Auditor Change Jointly Predicting Firm Bankruptcy

Equation (3) shows the logistic regression model for auditor qualified opinion and auditor changes considered jointly in predicting pending firm failure. The existing research regarding auditor modified opinions and auditor changes in identifying bankrupt companies suggests that both auditor qualified opinions and auditor changes should be positively associated with bankruptcy but that auditor changes should be positively associated to a smaller degree than auditor qualified opinions. In addition, logistic regression Equation (3) allows us to test the incremental explanatory power of auditor changes beyond the information conveyed by auditor qualified opinions alone in predicting pending firm failure by testing whether the regression coefficient on the auditor change variable is significantly greater than zero when the qualified auditor opinion variable is present in the model specification. Consequently, we a priori believe that $c_{1}$ and $c_{2}$ will be significantly greater than zero at the $\square=0.05$ confidence level and we individually test the null hypotheses $\mathrm{H}_{03}: \mathrm{c}_{1} \square 0$ and $\mathrm{H}_{04}: \mathrm{c}_{2} \square 0$ employing Equation (3) below. $\mathrm{H}_{04}: \mathrm{c}_{2} \square 0$ specifically addresses and tests the hypothesis regarding the incremental explanatory power of auditor changes beyond the information communicated by qualified auditor opinions. While we expect auditor changes to provide valuable information in predicting bankruptcy above that communicated by qualified auditor changes based upon the contingency tables and chi-squared tests presented in Table 3 and in prior research such as Schwartz and Menon [1985], we expect that the magnitude of the coefficient for auditor changes is smaller than that for qualified auditor opinions and consequently we also test the null hypothesis $\mathrm{H}_{05}: \mathrm{c}_{1}-\mathrm{c}_{2} \square 0$.

Probability of Firm Bankruptcy $=c_{0}+c_{1}$. Qualified ${ }_{i}+c_{2}$. Change $e_{i}+e_{3 i}$

\section{Model 4: Auditor Qualified Opinion \& Financial Ratios Jointly Predicting Firm Bankruptcy}

Equation (4) shows the logistic regression model to examine the incremental explanatory power of auditor qualified opinion given the traditional financial statement ratios used in prediction of pending bankruptcy. Specified in this manner the logistic regression model tests the incremental explanatory power of auditor qualified opinion by null hypotheses testing whether the regression coefficient on the auditor qualified opinion variable is statistically significant. Extant literature indicates that the logistic regression model coefficient for going concern and consistency auditor qualified opinions is significantly greater than zero at the $\square=0.05$ confidence level. However, the incremental explanatory power of auditor qualified opinion without the going concern or consistency type of qualification is an open empirical question. As a result, we expect that $\mathrm{d}_{7}$ will be significantly greater than zero at the $\square=0.05$ confidence level and we test the null hypothesis $\mathrm{H}_{06}: \mathrm{d}_{7} \square 0$ employing Equation (4) below.

Probability of Firm Bankruptcy $=d_{0}+d_{1} \cdot X 1_{i}+d_{2} \cdot X 2_{i}+d_{3} \cdot X 3_{i}+d_{4} \cdot X 4_{i}+d_{5} \cdot X 5_{i}+d_{6} \cdot X 6_{i}+d_{7} \cdot Q$ Qualified $d_{i}+e_{4 i}$

\section{Model 5: Auditor Change \& Financial Ratios Jointly Predicting Firm Bankruptcy}

Equation (5) illustrates the regression model specification we use to examine the incremental explanatory power of auditor changes given the traditional financial statement ratios used in prediction of pending bankruptcy. Specified in this manner the logistic regression model tests the incremental explanatory power of auditor changes by null hypotheses testing whether the regression coefficient on the auditor change variable is statistically significant. To our knowledge, the association between auditor changes and the probability of firm failure specified in this manner remains unexamined in the existing literature. Prior research literature provides evidence that sufficient a priori 
reason exists to expect the positive but marginally significant association between auditor changes and probability of firm failure. As a result, we expect that $f_{7}$ will be significantly greater than zero at the $\square=0.05$ confidence level and we test the null hypothesis $\mathrm{H}_{06}: \mathrm{f}_{7} \square 0$ employing Equation (5) below.

Probability of Firm Bankruptcy $=f_{0}+f_{1} \cdot X 1_{i}+f_{2} \cdot X 2_{i}+f_{3} \cdot X 3_{i}+f_{4} \cdot X 4_{i}+f_{5} \cdot X 5_{i}+f_{6} \cdot X 6_{i}+f_{7} \cdot$ Change $_{i}+e_{5 i}$

Model 6: Auditor Qualified Opinion, Auditor Change \& Financial Ratios Jointly Predicting Firm Bankruptcy

Equation (6) shows the logistic regression model specification for auditor qualified opinion and auditor changes considered jointly given the traditional financial statement ratios in predicting pending firm failure. The existing research regarding auditor qualified opinions given the traditional financial statement ratios in predicting bankruptcy suggests that auditor qualified opinions are positively associated with bankruptcy and that auditor qualified opinions convey information beyond that communicated by traditional financial statement ratios. To our knowledge, the extant literature shows no tests of the incremental information content of auditor changes in the manner specified in Equation (6). The logistic regression specified in Equation (6) provides us a means of testing the incremental explanatory power of auditor changes beyond the information conveyed by auditor qualified opinions and traditional financial statement ratios in predicting pending bankruptcy by testing whether the regression coefficient on the auditor change variable is significantly greater than zero when the qualified auditor opinion variable is present. Consequently, we a priori believe that $\mathrm{g}_{7}$ and $\mathrm{g}_{8}$ will be significantly greater than zero at the $\square=0.05$ confidence level and we individually test the null hypotheses $\mathrm{H}_{07}$ : $\mathrm{g}_{7} \square 0$ and $\mathrm{H}_{08}$ : $\mathrm{g}_{8} \square 0$ employing Equation (6) below. In order to test the incremental explanatory power of auditor changes beyond that communicated by auditor qualified opinions, we also test the null hypothesis $\mathrm{H}_{09}: \mathrm{g}_{7}-\mathrm{g}_{8} \square 0$.

Probability of Firm Bankruptcy $=g_{0}+g_{1} \cdot X 1_{i}+g_{2} \cdot X 2_{i}+g_{3} \cdot X 3_{i}+g_{4} \cdot X 4_{i}+g_{5} \cdot X 5_{i}+g_{6} \cdot X 6_{i}+g_{7} \cdot$ Qualified $_{i}+g_{8}$.

$$
\text { Change }_{\mathrm{i}}+\mathrm{e}_{6 \mathrm{i}}
$$

\section{Results of Empirical Model Estimation and Hypotheses Testing}

Testing Model 1, 2 \& 3: Relationship between Auditor Qualified Opinion and Auditor Changes on Bankruptcy Prediction

Table 5 shows the empirical results of auditor qualified opinion and auditor change explanatory variables used in estimating the logistic regression model shown in Equation (1) through Equation (3) and the related hypotheses tests specified in $\mathrm{H}_{01}$ through $\mathrm{H}_{05}$. Generally speaking, both auditor qualified opinions (Qualified ${ }_{\mathrm{i}}$ ) and auditor changes (Change ${ }_{\mathrm{i}}$ ) are significantly associated with increasing probability of bankruptcy as measured using the logistic regression model coefficients estimated in Equation (1) through Equation (3). And furthermore, all of the null hypotheses specified in $\mathrm{H}_{01}$ through $\mathrm{H}_{05}$ are rejected at the $\square=0.05$ confidence level.

Table 5 shows the logistic regression results for Equation (1) which tests the null hypothesis that auditor qualified opinions are not or negatively associated with probability of firm failure. As shown in Table 5 the coefficient $\mathrm{a}_{1}$ is positive and significantly greater than zero at the $\square=0.05$ confidence level and consequently $\mathrm{H}_{01}$ is rejected. ${ }^{4}$ This result is consistent with previous research and is enlightening because it extends the prior results to the other forms of qualified opinions in a time period during which the going concern opinion is no longer available as an auditor opinion modification format. The logistic regression results for Equation (2) indicate the $b_{1}$ is positive and significantly greater than zero at the $\square=0.05$ confidence level and consequently $\mathrm{H}_{02}$ is rejected. Consequently, we conclude that the probability of firm failure increases in relation to auditor changes. We are unaware of this result being reported in the existing research literature. The results for Equation (3) show that $\mathrm{c}_{1}$ is positive and significantly greater than zero at the $\square=0.05$ confidence level and that $c_{2}$ is positive and significantly greater than zero at the $\square=0.05$ confidence level, and consequently, $\mathrm{H}_{03}$ and $\mathrm{H}_{04}$ are rejected. In addition, $\mathrm{H}_{05}$ is rejected at the $\square=0.05$

\footnotetext{
4. The magnitude of the estimated logistic regression model coefficient is approximately three which in consistent with the range of the estimated logistic regression model coefficient values reported in Hopwood, McKeown, and Mutchler [1989, Table 4 p.42].
} 
confidence level indicating that the coefficient for qualified auditor opinions exceeds the coefficient for auditor changes. Consequently, we conclude that the coefficient for auditor changes is significantly greater than zero but is significantly less than the coefficient for auditor qualified opinions. Therefore, we believe that our study provides evidence that auditor changes provide an important source of information beyond that conveyed by qualified auditor opinions which is useful in predicting impending bankruptcy. We are unaware of similar results reported in the existing relevant research literature.

Table 5: Logistic Regression Models To Predict Firm Bankruptcy From Auditor Qualified Opinions And Auditor Changes

\section{Dependent Variable: Bankrupt}

\begin{tabular}{|l|c|c|c|c|c|c|}
\hline \multirow{2}{*}{} & \multicolumn{2}{|c|}{ Model 1 } & \multicolumn{2}{c|}{ Model 2 } & \multicolumn{2}{c|}{ Model 3 } \\
\cline { 2 - 7 } & Coefficient & $\mathrm{p}$-value & Coefficient & $\mathrm{p}$-value & Coefficient & $\mathrm{p}$-value \\
\hline Intercept & -2.5817 & 0.0001 & -0.2757 & 0.0001 & -2.8317 & 0.0001 \\
\hline Qualified $_{\mathrm{i}}$ & $\mathrm{a}_{1}=2.9991$ & $0.0001^{*}$ & \multicolumn{2}{|c|}{ Not in model } & $\mathrm{c}_{1}=2.9198$ & $0.0001^{*}$ \\
\hline Change $_{\mathrm{i}}$ & \multicolumn{2}{|c|}{ Not in model } & $\mathrm{b}_{1}=0.7564$ & $0.0001^{*}$ & $\mathrm{c}_{2}=0.6275$ & $0.0001^{*}$ \\
\hline Model R $^{2}$ & 0.1470 & 0.0344 & & 0.1646 & \\
\hline Concordance & $27.5 \%$ & & $35.2 \%$ & & $51.3 \%$ & \\
\hline Discordance & $1.4 \%$ & & $26.5 \%$ & & $14.0 \%$ & \\
\hline
\end{tabular}

* Coefficient is significantly different from zero at $\alpha=0.05$ confidence level.

Results of Hypothesis Testing:

Model 1, Equation 1: $\mathrm{H}_{01}: \mathrm{a}_{1} \leq 0$ is rejected at the $\alpha=0.05$ confidence level.

Model 2, Equation 2: $\mathrm{H}_{02}: \mathrm{b}_{1} \leq 0$ is rejected at the $\alpha=0.05$ confidence level.

Model 3, Equation 3: $\mathrm{H}_{03}: \mathrm{c}_{1} \leq 0$ is rejected at the $\alpha=0.05$ confidence level.

Model 3, Equation 3: $\mathrm{H}_{04}: \mathrm{c}_{2} \leq 0$ is rejected at the $\alpha=0.05$ confidence level.

Model 3, Equation 3: $\mathrm{H}_{05}: \mathrm{c}_{1}-\mathrm{c}_{2} \leq 0$ is rejected at the $\alpha=0.05$ confidence level. The null hypothesis of no difference in the two coefficients is rejected, $\chi^{2}=18.4849$ with $\mathrm{p}$-value of $<0.0001$.

Variable Definitions:

$\begin{aligned} \text { Bankrupt }_{\mathrm{i}} & =1, \text { if } \mathrm{i}^{\text {th }} \text { firm is Bankrupt } \\ & =0, \text { if } \mathrm{i}^{\text {th }} \text { firm is NOT Bankrupt } \\ \text { Qualified }_{\mathrm{i}} & =1, \text { if } \mathrm{i}^{\text {th }} \text { firm received a qualified auditor opinion } \\ & =0, \text { if } \mathrm{i}^{\text {th }} \text { firm did NOT receive a qualified auditor opinion } \\ \text { Change }_{\mathrm{i}} & =1, \text { if } \mathrm{i}^{\text {th }} \text { firm had changed auditor } \\ & =0, \text { if } \mathrm{i}^{\text {th }} \text { firm did NOT change auditor }\end{aligned}$

Testing Model 4, 5 \& 6: Relationship Between Auditor Qualified Opinion, Auditor Changes And Financial Ratios On Bankruptcy Prediction

The logistic regression results for Equations (4) through Equation (6) as well as the related null hypotheses tests for $\mathrm{H}_{06}$ through $\mathrm{H}_{010}$ are presented in Table 6. In Equations (4) through Equation (6) we test the incremental explanatory power of qualified auditor opinions and auditor changes in predicting firm failure beyond that conveyed by traditional financial statement ratios by testing the significance of the logistic regression coefficients on auditor qualified opinions and auditor changes. In addition, we test the incremental explanatory power of auditor changes above information communicated traditional financial statement ratios and qualified auditor opinions. We are not aware of any study in the existing literature which tests such hypotheses.

In general, both auditor qualified opinions and auditor changes are significantly associated with increasing probability of bankruptcy after controlling for the information reflected in traditional financial statement ratios as 
measured using the estimated coefficients in Equation (4) through Equation (6) and all of the null hypotheses in $\mathrm{H}_{06}$ through $\mathrm{H}_{10}$ are rejected at the $\square=0.05$ confidence level. Particularly noteworthy, we find that auditor changes are significantly and positively associated with the probability of bankruptcy after holding constant traditional financial statement variables and auditor qualified opinion. We conclude the auditor changes communicate valuable information beyond that conveyed by traditional financial statement ratios and auditor qualified opinions in predicting firm failure.

Table 6: Logistic Regression Models to Predict Firm Bankruptcy from Auditor Qualified Opinions, Auditor Changes and Financial Ratios

Dependent Variable: Bankrupt

\begin{tabular}{|c|c|c|c|c|c|c|}
\hline & \multicolumn{2}{|c|}{ Model 4} & \multicolumn{2}{|c|}{ Model 5} & \multicolumn{2}{|c|}{ Model 6} \\
\hline & Coefficient & p-value & Coefficient & p-value & Coefficient & $\mathrm{p}$-value \\
\hline Intercept & -3.3013 & 0.0001 & -1.0252 & 0.0001 & -3.564 & 0.0001 \\
\hline $\mathrm{X} 1=\mathrm{Cash} /$ Total Assets & $\mathrm{d}_{1}=-1.511$ & $0.0340 *$ & $\mathrm{f}_{1}=-1.771$ & $0.0082 *$ & $\mathrm{~g}_{1}=-1.492$ & $0.0379 *$ \\
\hline X2=Current Assets/Current Liab. & $\mathrm{d}_{2}=-0.124$ & $0.0266^{*}$ & $f_{2}=-0.151$ & $0.0140 *$ & $\mathrm{~g}_{2}=-0.113$ & $0.0439 *$ \\
\hline X3=Current Assets/Sales & $\mathrm{d}_{3}=-0.009$ & 0.4575 & $f_{3}=-0.0073$ & 0.4579 & $\mathrm{~g}_{3}=-0.008$ & 0.4957 \\
\hline $\mathrm{X} 4=$ Current Assets/Total assets & $\mathrm{d}_{4}=1.258$ & $0.0017 *$ & $\mathrm{f}_{4}=1.1787$ & $0.0027 *$ & $\mathrm{~g}_{4}=1.2409$ & $0.0023 *$ \\
\hline X5=Long Term Debt/Total Assets & $\mathrm{d}_{5}=0.296$ & 0.2651 & $f_{5}=0.5997$ & $0.0381 *$ & $\mathrm{~g}_{5}=0.3663$ & 0.1901 \\
\hline X6=Net Income/Total Assets & $\mathrm{d}_{6}=-1.209$ & $0.0001 *$ & $\mathrm{f}_{6}=-1.632$ & $0.0001 *$ & $\mathrm{~g}_{6}=-1.278$ & $0.0001 *$ \\
\hline Qualified $_{\mathrm{i}}$ & $\mathrm{d}_{7}=2.9806$ & $0.0001 *$ & \multicolumn{2}{|c|}{ Not in model } & $\mathrm{g}_{7}=2.8556$ & $0.0001 *$ \\
\hline Change $_{i}$ & \multicolumn{2}{|c|}{ Not in model } & $\mathrm{f}_{7}=0.8299$ & $0.0001 *$ & $\mathrm{~g}_{8}=0.6724$ & $0.0002 *$ \\
\hline Model R ${ }^{2}$ & 0.2245 & & 0.1676 & & 0.2410 & \\
\hline Concordance & $81.3 \%$ & & $79.2 \%$ & & $81.4 \%$ & \\
\hline Discordance & $18.4 \%$ & & $20.5 \%$ & & $18.4 \%$ & \\
\hline
\end{tabular}

* Coefficient is significantly different from zero at $\alpha=0.05$ confidence level.

Results of Hypothesis Testing:

Model 4, Equation 4: $\mathrm{H}_{06}: \mathrm{d}_{7} \leq 0$ is rejected at the $\alpha=0.05$ confidence level.

Model 5, Equation 5: $\mathrm{H}_{07}: \mathrm{f}_{7} \leq 0$ is rejected at the $\alpha=0.05$ confidence level.

Model 6, Equation 6: $\mathrm{H}_{08}: \mathrm{g}_{7} \leq 0$ is rejected at the $\alpha=0.05$ confidence level.

Model 6, Equation 6: $\mathrm{H}_{09}: \mathrm{g}_{8} \leq 0$ is rejected at the $\alpha=0.05$ confidence level.

Model 6, Equation 6: $\mathrm{H}_{10}: \mathrm{g}_{7}-\mathrm{g}_{8} \leq 0$ is rejected at the $\alpha=0.05$ confidence level. The null hypothesis of no difference in the two coefficients is rejected, $\chi^{2}=14.9443$ with $p$-value of $<0.0001$.

\section{Variable Definitions:}

Bankrupt $i=1$, if $i^{\text {th }}$ firm is Bankrupt $=0$, if $i^{\text {th }}$ firm is NOT Bankrupt

Qualified $_{i}=1$, if $i^{\text {th }}$ firm received a qualified auditor opinion $=0$, if $i^{\text {th }}$ firm did NOT receive a qualified auditor opinion

Change $_{\mathrm{i}}=1$, if $\mathrm{i}^{\text {th }}$ firm had changed auditor $=0$, if $i^{\text {th }}$ firm did NOT change auditor

$\mathrm{X} 1 \ldots \mathrm{X} 6 \quad$ Various financial ratios as described in the table above

Table 6 presents the estimated logistic regression results for Model 4, Equation (4) which is used to test the null hypothesis shown in $\mathrm{H}_{06}$ that auditor qualified opinions are negatively associated with probability of firm failure holding constant the relevant information convey by traditional financial statement ratios. As indicated in Table 6 the estimated coefficient $d_{7}$ is positive and significantly greater than zero at the $\square=0.05$ confidence level. Consequently $\mathrm{H}_{06}$ is rejected. This result is consistent with prior research and is noteworthy as it replicates the results of previous research using the types of qualified opinions other than the going concern qualification and does so in a time period 
during which the going concern opinion is absent.

The logistic regression results for Model 5, Equation (5) are also presented in Table 6. These results indicate that $\mathrm{f}_{7}$ is positive and significantly greater than zero at the $\square=0.05$ confidence level and therefore $\mathrm{H}_{07}$ is rejected. As a result, we infer that the probability of firm bankruptcy increases in relation to auditor changes holding constant the other information provided by traditional financial statement variables.

Table 6 also illustrates the results for Model 6, Equation (6). As show, $g_{7}$ is positive and significantly greater than zero at the $\square=0.05$ confidence level and $\mathrm{g}_{8}$ is positive and significantly greater than zero at the $\square=0.05$ confidence level as well. Consequently, $\mathrm{H}_{08}$ and $\mathrm{H}_{09}$ are both rejected at the $\square=0.05$ confidence level. In addition, $\mathrm{H}_{10}$ is rejected at the $\square=0.05$ confidence level indicating that the logistic regression coefficient for qualified auditor opinions is significantly greater than the coefficient for auditor changes at the $\square=0.05$ confidence level. Consequently, based upon the previous hypotheses tests taken together we conclude that the coefficient for auditor changes is significantly greater than zero but remains significantly less than the coefficient for qualified auditor opinions at the $\square=0.05$ confidence level after controlling for the information conveyed by traditional financial statement ratios and qualified auditor opinions. Therefore, we believe that this research study provides compelling empirical evidence that auditor changes provide an important source of information beyond that conveyed by qualified auditor opinions and traditional financial statement variables which is useful in predicting impending bankruptcy. We are unaware of similar results reported in the existing relevant research literature and believe that this observation is the unique contribution of this study to the existing relevant research literature.

\section{CONCLUSION}

The purpose of this study was to contribute to the existing research literature by providing reliable empirical results regarding auditor changes as an explanatory variable along with auditor qualified opinions in predicting firm failure. The current research literature has ascertained the incremental explanatory power of certain types of prior auditor qualified opinions in predicting bankruptcy (Hopwood, McKeown, and Mutchler [1989, 1991]). Our empirical method tests numerous null hypotheses designed to provide the bases for statistical inferences concerning the following issues: (1) the explanatory power of auditor qualified opinions and client audit firm changes for client financial failure; (2) the incremental explanatory power of audit firm changes above the information conveyed by auditor qualified opinions in predicting client financial failure; (3) the incremental explanatory power of auditor qualified opinions beyond that communicated by traditional financial statement ratios in predicting client firm failure; (4) the incremental explanatory power of client audit firm changes beyond the information conveyed by traditional financial statement ratios in predicting firm failure; and (5) the incremental explanatory power of client audit firm changes above the information communicated by auditor qualified opinions and traditional financial statement ratios in predicting bankruptcy.

The strongest contribution our empirical results make to the existing research literature are statistical inferences that qualitative information concerning client auditor changes preceding client bankruptcy provides statistically significant explanatory and incremental explanatory power in models predicting impending firm failure. The results of our statistical hypotheses tests provide compelling evidence that (1) both auditor modified opinions and client auditor changes are significantly positively associated with incidence of client firm bankruptcy; (2) client auditor changes have statistically significant incremental explanatory power beyond the information conveyed by qualified auditor opinions in predicting client firm bankruptcy; (3) both auditor qualified opinions and client auditor changes have statistically significant incremental explanatory power beyond the information conveyed by traditional financial statement ratios in predicting firm failure; and (4) auditor changes have statistically significant incremental explanatory power above the information provided by both traditional financial statement ratios and client auditor qualified opinions in models predicting impending firm financial failure. 


\section{REFERENCES}

1. Altman, E. I. Financial ratios, discriminate analysis, and the prediction of corporate bankruptcy. The Journal of Finance. (September 1968): 589-609.

2. and T. McGough. Evaluation of a company as a going-concern. Journal of Accountancy. (December 1974): 50-57.

3. Altman, E., R. Haldeman, and P. Narayanan. Zeta analysis - a new model to identify bankruptcy risk of corporations. Journal of Banking and Finance. (1977 1): 29-54.

4. Antle, R. and B. Nalebuff. Conservatism and auditor-client negotiations. Journal of Accounting Research. (Supplement 1991): 31-59.

5. Balachandran, B. and R. Ramakrishnan. A theory of audit partnerships: Audit firm size and fees. Journal of Accounting Research. (1987 25): 111-126.

6. Beaver, W. H. Financial ratios as predictors of failure. Journal of Accounting Research. (Supplement 1966): 71-111.

7. Boritz, J. The 'going concern' assumption: accounting and auditing implications. Research Report. Canadian Institute of Chartered Accountants (1991 Toronto, Canada).

8. Chen, C. W. and B. K. Church. Default on debt obligations and the issuance of going concern opinions. Auditing: A Journal of Theory and Practice. (Fall 1992): 30-49.

9. Chow, C. W. and S. J. Rice. Qualified audit opinions and auditor switching. The Accounting Review. (April 1982): 326-335.

10. Collins, R. An empirical comparison of bankruptcy prediction models. Financial Management. (Summer 1980): 51-57.

11. Connor, J. E. Enhancing public confidence in the accounting profession. Journal of Accountancy. (July 1986): 76-83.

12. Deakin, E. B. A discriminant analysis of predictors of business failure. Journal of Accounting Research. (Spring 1972): 167-179.

13. DeFond, M. and J. Jiambalvo. Factors related to auditor-client disagreements over income increasing accounting methods. Contemporary Accounting Research. (1993 9): 415-431.

14. Dye, R. Informationally motivated auditor replacement. Journal of Accounting and Economics. (14 1991): 347-374.

15. Hamer, M. Failure prediction: sensitivity of classification accuracy to alternative statistical methods and variable sets. Journal of Accounting and Public Policy. (2 1983): 289-307.

16. Hopwood, W., J. C. McKeown, and J. F. Mutchler. A reexamination of auditor versus model accuracy within the context of the going-concern opinion decision. Contemporary Accounting Research. (Spring 1994): 409-431.

17. Journal of Accountancy. Special report - ASB public meeting on 'subject-to' opinion. (August 1982): 1014.

18. Journal of Accountancy. News Report Section. (February 1983): 9-24.

19. Karels, Gordon V. and Prakash. Multivariate normality and forecasting of business bankruptcy. Journal of Business Finance \& Accounting. Winter 1987, Vol. 14 Issue 4, 573-593.

20. Krishnan, J. and J. Krishnan. The role of economic trade-offs in audit opinion decision: An empirical analysis. Journal of Accounting, Auditing, and Finance. (11 1996): 565-586.

21. Levitan, A. and J. Knoblett. Indicators of exceptions to the going-concern assumption. Auditing: A Journal of Theory and Practice. (Fall 1985): 26-39.

22. Libby, R. The use of simulate decision makers in information evaluation. The Accounting Review. (July 1975): 475-489.

23. Lys, T., and R. Watts. Lawsuits against auditors. Journal of Accounting Research. (1994 Supplement): 6593.

24. Magee, R. and M. Tseng. Audit pricing and independence. The Accounting Review. (1990 65): 315-336.

25. McConnell, D. K. Are the big 8 increasing their share of the NYSE, AMEX, and OTC audit markets? Journal of Accounting, Auditing, and Finance. (Winter 1984): 178-181.

26. McKeown, J. C., J. F. Mutchler, and W. Hopwood. Towards an explanation of auditor failure to modify the audit opinions of bankrupt companies. Auditing: A Journal of Theory and Practice. (Supplement 19913): 1- 
13.

27. Mednick, R. The auditor's role in society: A new approach to solving the perception gap. Journal of Accountancy. (February 1986): 70-74.

28. Mutchler, J. F. Empirical evidence regarding the auditor's going-concern opinion decision. Auditing: A Journal of Theory and Practice. (Fall 1986): 148-163.

29. Ohlson, J. Financial ratios and the probabilistic prediction of bankruptcy. Journal of Accounting Research. (18 1987): 109-131.

30. Platt, H. and M. Platt. A note on the use of industry firm bankruptcy. Journal of Banking and Finance. (15 1991): 1183-1194.

31. Pratt, J. and J. Stice. The effects of client characteristics on auditor litigation risk adjustments, required audit evidence, and recommended audit fees. The Accounting Review. (1994 69): 639-656.

32. Schwartz, K. B. and K. Menon. Auditor switches by failing firms. The Accounting Review. (April 1985): 248-261.

33. Simunic, D. and M. Stein. The impact of litigations risk on audit pricing: A review of the economics and evidence. Auditing: A Journal of Theory and Practice. (1996 15): 119-134.

34. St. Pierre, K. and J. Anderson. An analysis of the factors associated with lawsuits against public accountants. The Accounting Review. (1984 59): 242-263.

35. Zmijewski, M. Methodological issues related to the estimation of financial distress prediction models. Journal of Accounting Research. (Supplement 22 1984): 59-86. 